\title{
Happiness, work engagement and organisational commitment of support staff at a tertiary education institution in South Africa
}

\author{
Authors: \\ Lyndsay K. Field ${ }^{1}$ \\ Johanna H. Buitendach ${ }^{1}$ \\ Affiliations: \\ ${ }^{1}$ School of Psychology, \\ Howard College, University of \\ KwaZulu-Natal, South Africa \\ Correspondence to: \\ Lyndsay Field \\ Email: \\ 207510955@ukzn.ac.za \\ Postal address: \\ Department of Psychology, \\ University of KwaZulu-Natal, \\ Private Bag X54001, Durban \\ 4012, South Africa \\ Dates: \\ Received: 03 Dec. 2010 \\ Accepted: 18 May 2011 \\ Published: 19 Sept. 2011 \\ How to cite this article: \\ Field, L.K., \& Buitendach, \\ J.H. (2011). Happiness, \\ work engagement and \\ organisational commitment \\ of support staff at a tertiary \\ education institution in \\ South Africa. SA Journal of \\ Industrial Psychology/SA \\ Tydskrif vir Bedryfsielkunde, \\ 37(1), Art. \#946, 10 pages. \\ doi:10.4102/sajip.v37i1.946 \\ Note: \\ The material in this article \\ is based upon work that \\ the National Research \\ Foundation, under a NRF \\ freestanding bursary, \\ supports.
}

Orientation: Support staff members play a vital role in tertiary education institutions. With this in mind, the institutions must address their particular needs. In the context of positive psychology, issues of happiness and work engagement could lead to increased positive organisational outcomes like the commitment of support staff.

Research purpose: The purpose of the research was to determine the relationship between happiness, work engagement and organisational commitment and to determine whether happiness and work engagement hold predictive value for the organisational commitment of support staff.

Motivation for the study: This study aims to enable the identification of a link between happiness, work engagement and organisational commitment and to identify a predictive value of the model.

Research design, approach and method: The researchers used a cross-sectional survey design. They used a sample of $123(N=123)$ support staff members from a tertiary education institution in South Africa. The researchers used four demographic questionnaires for the research. These were the 'Satisfaction with Life Scale' (SWLS), the 'Well-Being Questionnaire' (WBQ), the 'Utrecht Work Engagement Scale' (UWES) and the 'Organisational Commitment Questionnaire' (OCQ).

Main findings: The researchers found a significant positive relationship between affective organisational commitment and work engagement, as well as between affective organisational commitment and happiness (as the SWLS and WBQ measure). They found a significant positive relationship between work engagement and happiness. Finally, the results showed that happiness and work engagement have predictive value for affective organisational commitment.

Practical/managerial implications: Happiness and work engagement have predictive value for affective organisational commitment. Therefore, institutions should carefully tailor any implementation programme or initiative to address this relationship.

Contribution/value-add: The findings will benefit both managers and workers. Institutions should consider evaluating the levels of happiness and work engagement of their support staff to address the issue of the organisational commitment of their employees.

\section{Introduction}

\section{Positive psychology}

The focus of psychological literature has traditionally been situated within a biomedical model, resulting in a focus on negative, rather than positive, states (Seligman \& Csikszentmihalyi, 2000). Positive states have not traditionally captured the attention of psychologists (Bakker, Schaufeli, Leiter \& Taris, 2008).

More recently, however, there has been a shift toward a more 'positive psychology', where the prime focus is on positive states of being (Maddux, 2008). The emergence of a more positively orientated psychology in turn has resulted in the concepts of well-being and happiness appearing increasingly in psychological literature and particularly in organisational psychological literature (Money, Hillenbrand \& Da Camara, 2008).

Tertiary education institutions present an interesting context within which to study issues of wellbeing and positive states at work. There are a several reasons for this.
(C) 2011. The Authors. Licensee: AOSIS OpenJournals. This work is licensed under the Creative Commons Attribution License. 
Firstly, in the South African context, tertiary education institutions play a vital role in the ongoing transformation of the country. Therefore, it is important that these institutions attend to the people they employ through research (Coetzee \& Rothmann, 2005).

Secondly, although support staff members contribute greatly to the functioning of effective tertiary institutions, most studies overlook them and focus mainly on academic staff (Barkhuizen \& Rothmann, 2006; Jackson \& Rothmann, 2005).

Thirdly, support staff members often face tedious workloads and play various supportive roles to ensure the functioning of tertiary education institutions. Because they comprise a great deal of the 'human capital' of these institutions, there is a great need to ensure that they experience optimum levels of psychological well-being at work.

Although there has been some research on the relationship between work engagement and organisational commitment, there is little information on the relationship between the three constructs of happiness, work engagement and organisational commitment. Scientific knowledge about the possible relationships between these constructs can be very valuable to the ever-expanding body of knowledge linked to positive psychology in the workplace.

The objective of this study was to investigate the relationship between happiness, work engagement and organisational commitment and to investigate the predictive value of happiness and work engagement for organisational commitment.

\section{Happiness}

Ryan and Deci (2001, p. 142) define well-being as 'optimal psychological functioning and experience'. In the literature, well-being is not simply the absence of mental illness. It is something over and above the simple dichotomy of mental illness and its absence.

The concept of subjective well-being (SWB) has become the major focus of studies of well-being. It refers to the ways people evaluate how happy they are or how good their quality of life is using their own subjective perceptions of happiness and well-being (Ryan \& Deci, 2001; Susniene \& Jurkauskas, 2009). Uchida, Norasakkunkit and Kitayama (2004, p. 223) define SWB as 'an overall cognitive appraisal of the quality of one's own life'.

The present study uses the term 'happiness' as it includes the concepts of well-being and of SWB. Uchida et al. (2004, p. 61) define happiness as a 'high ratio of positive to negative feelings'. Therefore, a positive and affective emotional and psychological state characterises happiness.

There are two traditional perceptions of happiness in the literature. These are the hedonic view and the eudaimonic view (Ryan, Huta \& Deci, 2008). Traditionally, these perceptions exist independently of one another. However, they do have similarities.

The hedonic view of well-being is one with a long history (Ryan \& Deci, 2001). Hedonism tries to maximise pleasure and minimise pain. The pursuit of pleasure is the way to achieve happiness. The saying 'don't worry - be happy' encapsulates the philosophy (Peterson, Park \& Seligman, 2005, p. 26).

Proponents of this view argue that happiness is thus not reducible to physical hedonism, for it can be derived from attainment of goals or valued outcomes in varied realms' (Ryan \& Deci, 2001, p. 144).

In the eudaimonic view, happiness comes from identifying one's virtues and living accordingly (Ryan \& Deci, 2001). The eudaimonic approach sees happiness as different to simply experiencing pleasure by positing that 'well-being calls upon people to live in accordance with their daimon, or true self' (Ryan \& Deci, 2001, p. 146). This approach sees achieving happiness as a process rather than as a state. The eudaimonic approach argues that outcomes, even though they do not bring immediate pleasure, can promote happiness (Ryan \& Deci, 2001).

Ryan et al. (2008) argue that hedonic thinking leads to shortterm happiness, whereas eudaimonic living leads to a more enduring and lasting happiness. Ryan et al. (2008) also postulate that eudaimonia refers to a lifestyle and a way of living that specific measurable outcomes cannot define.

Both of these approaches offer a route to happiness. One cannot see them as completely independent of each another because people can experience happiness via the hedonic route (experiencing immediate pleasure that leads to happiness) and the eudaimonic route (deriving long-lasting and enduring happiness from living in accordance with ones true self) (Ryan et al., 2008). Critics, like Kahneman (2000), argue that people cannot evaluate how happy they really are.

It is clear that happiness is a concept that studies of wellbeing should measure.

The context of work and the organisation as a whole now accommodate notions of positive psychology and wellbeing studies (Money, Hillenbrand \& Da Camara, 2008). They suggest that work, through a positive psychology lens, could cause people to lead more engaged, pleasurable and meaningful work lives. These, in turn, would benefit the organisation as a whole and the individual employee (Money et al., 2008). The belief that happiness acts as a causal mechanism that brings about many positive states within the workplace is at the heart of positive organisational psychology (Money et al., 2008).

Happiness in the workplace includes many different aspects like work engagement and job satisfaction. These, in turn, 
lead to several positive organisational outcomes (Fisher, 2010). A study that Gavin and Mason (2004) conducted also shows that happiness and positive states of people at work contribute to increased organisational success and commitment.

The literature suggests that happiness at work leads to various positive organisational outcomes (Fisher, 2010; Gavin \& Mason, 2004; Money et al., 2008). However, we do not really know much about the relationship between happiness, work engagement and organisational commitment.

The literature suggests that there is a link between these variables. The possible connection between these variables is that happiness encompasses many constructs, one being that of work engagement (Money et al., 2008). This, in turn, results in positive organisational outcomes, one of which is organisational commitment (Gavin \& Mason, 2004; Money et al., 2008).

\section{Work engagement}

Kahn (1990, p. 694) sees engagement as the '... harnessing of organization member's selves to their work roles: in engagement, people employ and express themselves physically, cognitively, emotionally and mentally during role performances'. Schaufeli, Salanova, Gonzalez-Roma and Bakker (2002) define engagement as a persistent and positive affective-motivational state of fulfilment. Bakker et al. (2008) see work engagement as 'a positive, fulfilling, affective motivational state of work-related well-being that is characterized by vigour, dedication and absorption' (p. 187). Engaged employees are enthusiastic and energetic about their work and fully immersed in it, to such an extent that time seems to pass quickly whilst they are working (Bakker $e t$ al., 2008; Bakker \& Demerouti, 2008). Clearly, the concept of work engagement is embedded in a more positive ideology about psychological well-being and its constituents because work engagement is a positive state (Bakker et al., 2008).

The literature has conceptualised work engagement in two ways. Firstly, it is the antithesis of burnout. Secondly, it sees work engagement as separate and unrelated to burnout (Schaufeli \& Bakker, 2004).

The second, and more accepted one, suggests that work engagement encapsulates vigour (high energy levels and mental resiliency whilst working), dedication (being strongly involved, and deriving a sense of achievement, in one's work) and absorption (being fully engrossed in one's work so that time passes quickly whilst working; see Bakker et al., 2008). Previous research on work engagement has found a positive relationship between work engagement and age (Coetzee \& Rothmann, 2005).

Researchers have investigated the relationship between work engagement and organisational commitment (Chalofsky \& Krishna, 2009). Most research incorporates the concept of organisational commitment as an aspect of work engagement.
Consequently, it sees a positive relationship between the two concepts of work engagement and work commitment.

With regard to the relationship between work engagement and organisational commitment, those that are highly engaged in their work also tend to be committed to their organisations. Therefore, there is a positive correlation between work engagement and organisational commitment (Rothmann \& Jordaan, 2006). In addition, the literature shows that work engagement is an antecedent of organisational commitment because people who are deeply engaged in their work tend to be more committed to their organisations (Jackson, Rothmann \& Van de Vijver, 2006; Saks, 2006).

\section{Organisational commitment}

One can define organisational commitment as the willingness of employees to make greater effort on behalf of their organisations, a strong desire to remain in their organisations and accept their major goals and values (Porters, Steers, Mowday \& Boulin, 1974). One can also define it as the employee's feelings of obligation to stay with their organisations. These feelings result from the normative pressures employees experience (Allen \& Meyer, 1990; Viljoen \& Rothmann, 2009).

According to Allen and Meyer (1990), three distinct components (a three-component framework) can characterise organisational commitment. These are the affective, continuance and normative components.

The affective component refers to the employees' identification with, involvement in and attachment to their organisations because they want to (Allen \& Meyer, 1991). The basis of the continuance component is the employees' evaluations of the costs of leaving or discontinuing a particular activity in their organisations. These employees will stay with their organisations because they perceive poor alternatives or high costs associated with leaving (Allen \& Meyer, 1990). The normative component refers to a sense of obligation to the organisations. In other words, according to Allen and Meyer (1990), they feel responsible and loyal to their organisations because it is the correct and moral thing to do:

Employees with strong affective commitment remain because they want to, those with strong continuance commitment because they need to, and those with strong normative commitment because they feel they ought to.

(Allan \& Meyer, 1990, p. 3)

It is important to note that these three forms of commitment are not mutually exclusive because employees can experience all three forms of commitment in varying degrees (Allen \& Meyer, 1991). Many studies have focused on the affective commitment component as being particularly prominent (Rhoades, Eisenberger \& Armeli, 2001).

\section{Theoretical framework}

The theoretical framework underlying this study is the Self Determination Theory, or SDT (Deci \& Ryan, 1985). The 
SDT sees motivation on a continuum. Amotivation is at one end, which is no motivation at all, and intrinsic motivation is at the other. Extrinsic motivation lies in the middle of the continuum. There are four types of extrinsic motivation (Gagne \& Deci, 2005).

The SDT proposes that there are two overarching forms of motivation. These are intrinsic and extrinsic motivation. Intrinsic motivation refers to doing an activity for its own sake. One engages in a particular activity to enjoy it or for fulfilment (Meyer \& Gagne, 2008). Extrinsic motivation refers to engaging in an activity for instrumental reasons (Meyer \& Gagne, 2008). Extrinsic motivation can take on different forms. They include external regulation (doing something to receive reward or avoid punishment) and integration (expressing one's sense of self) (Gagne \& Deci, 2005).

According to the SDT, the 'key to autonomous regulation is satisfaction of basic psychological needs' (Meyer \& Gagne, 2008, p. 61). Here, needs are universal necessities that are essential for optimal human development.

Therefore, in order for people to experience psychological growth, integrity and well-being they must satisfy three basic and universal psychological needs. These basic psychological needs are autonomy, competence and relatedness (Cankaya, 2009; Deci \& Ryan, 2000; Ryan \& Deci, 2001). People can only experience a sense of happiness in their lives when they have met their needs for autonomy, competence and relatedness.

In essence, the SDT postulates that happiness and positive psychological well-being result from the extent to which people are able to satisfy their basic universal psychological needs in their social environments (Gagne \& Deci, 2005).

In the context of this study, and working from the theoretical basis of the SDT, the researchers postulate that satisfying the psychological needs of autonomy, competence and relatedness at work leads people to experience high levels of happiness and psychological well-being. The researchers extended this theoretical model to propose that the happiness of people at work, in turn, leads to increased positive organisational outcomes (Gavin \& Mason, 2004).

With this as a theoretical basis, the present study proposes a model to investigate whether happiness and work engagement can predict organisational commitment.

In South Africa, there have been numerous studies on levels of engagement and (to a lesser extent) the commitment of school educators as well as staff in tertiary education institutions (Coetzee \& Rothmann, 2005; Jackson et al., 2006; Rothmann \& Jordaan, 2006).

These studies have found that one can see work engagement as a concept related to happiness, that happiness is an antecedent to positive organisational outcomes and that work engagement is an antecedent of organisational commitment.
However, there has been little research to investigate whether there is a relationship between these three constructs.

We need research on the relationship between happiness, work engagement and organisational commitment to add to the existing body of knowledge about positive psychology and the importance of positive states at work as they affect positive organisational outcomes.

In addition, there has been little research on whether happiness and work engagement can predict organisational commitment. The present study aims to address this gap in the current literature.

Based on a review of the literature, the researchers proposed the hypotheses that follow:

- Hypothesis 1: There is a positive relationship between happiness, work engagement and organisational commitment.

- Hypothesis 2: Happiness and work engagement can predict organisational commitment.

\section{Research design Research approach}

The specific design the researchers used in this study was cross-sectional. They drew a sample from the population at a specific time and point (Shaughnessy \& Zechmeister, 1997). A cross-sectional research design typically consists of different people that researchers examine using one or more variables (Huysamen, 1994).

The researchers also assessed the interrelationships between variables in the sample. According to Shaughnessy and Zechmeister (1997), this design is ideally suited to descriptive and predictive functions and is appropriate for this particular study.

The researchers received approval for this study as it fulfilled ethical requirements.

\section{Research method Research participants}

The researchers selected the sample using a nonprobability convenience sampling method. They used this method because it is the most convenient way of collecting data from support staff because they did not know which staff members would be at the university on a particular day. They also chose this sampling method because it is less complicated, less time consuming and more economical (Huysamen, 1994).

The research participants were support staff members who worked at the University of KwaZulu-Natal in South Africa.

The sample comprised more women (69.9\%) than it did men $(30.1 \%)$. This is acceptable because there are more women than men support staff. The men in the sample worked mainly in information communication and technical positions. 
Most participants (35\%) were 25-35 years old. Twenty-two per cent were $36-45$ years old, $22 \%$ came from the $46-55$ age group, $14.6 \%$ from the 24 and younger age group and $6.5 \%$ from the 56 and older age group.

With regard to marital status, $49.6 \%$ were single and $40.7 \%$ were married.

Most participants (44.7\%) had worked for the university for fewer than five years. Fairly equal numbers had worked for 6-10 years (18.7\%), $11-20$ years $(18.7 \%)$ and more than 20 years $(17.1 \%)$.

Of the participants, $27.6 \%$ had matriculation certificates as their highest qualification, $25.2 \%$ had diplomas, $23.6 \%$ had degrees and $22 \%$ had postgraduate degrees.

Of the sample, $26.8 \%$ held administrative posts at the university and $73.2 \%$ had other support staff posts (library, information and communication technology, sports department and electrical). This is acceptable because the number of administrative positions is substantially lower than that of other support staff positions at Howard College. The figures do not add to $100 \%$ because of missing data in some categories.

Table 1 gives the characteristics of the participants.

\section{Measuring instruments}

The researchers' data collection method consisted of four scales and a biographical data sheet that they developed in order to collect demographic information about the participants. They used this information purely for statistical purposes. The information they collected included the participants' genders, age groups, marital status, the number of years the participants had work for the university, their qualifications and their post descriptions.

The Satisfaction with Life Scale: The researchers used the SWLS (Diener, Emmons, Larsen \& Griffon, 1985) as one of the measures of happiness for this study. The SWLS is a 5-item Likert-type scale that measures life satisfaction as a cognitive-judgemental process. The SWLS includes statements like 'in most ways my life is close to ideal', and 'the conditions of my life are excellent'.

The researchers used the South African sample, the SWLS and a study by Roothman, Kirsten and Wissing (2003). They found a high alpha coefficient of 0.84 . This showed high levels of internal consistency between the scale items.

The Well-Being Questionnaire: The researchers used the WBQ (Bradley, 1994) as a measure of happiness in this study. The WBQ measures psychological well-being in people with a chronic somatic illness. However, it has also been used in the public as a measure of well-being (Pouwer, Snoek, Van der Ploeg, Heine \& Brand, 1998).

The researchers scored the WBQ using a 5-point Likert-type scale to measure depression, anxiety, energy and positive
TABLE 1: Characteristics of the participants.

\begin{tabular}{|c|c|c|c|}
\hline Characteristic & Frequency & $N$ & $\%$ \\
\hline \multicolumn{4}{|l|}{ Gender } \\
\hline Male & 37 & 123 & 30.1 \\
\hline Female & 86 & 123 & 69.9 \\
\hline \multicolumn{4}{|l|}{ Age group } \\
\hline 24 years and younger & 18 & 123 & 14.6 \\
\hline $25-35$ years & 43 & 123 & 35.0 \\
\hline $36-45$ years & 27 & 123 & 22.0 \\
\hline $46-55$ years & 27 & 123 & 22.0 \\
\hline 56 years and older & 8 & 123 & 6.5 \\
\hline \multicolumn{4}{|l|}{ Marital status } \\
\hline Single & 61 & 123 & 49.6 \\
\hline Divorced & 8 & 123 & 6.5 \\
\hline Widowed & 2 & 123 & 1.6 \\
\hline Married & 50 & 123 & 40.7 \\
\hline Living with a spouse & 2 & 123 & 1.6 \\
\hline \multicolumn{4}{|c|}{ Years worked at the organisation } \\
\hline Fewer than five years & 55 & 122 & 44.7 \\
\hline $6-10$ years & 23 & 122 & 18.7 \\
\hline $11-20$ years & 23 & 122 & 18.7 \\
\hline More than 20 years & 21 & 122 & 17.1 \\
\hline \multicolumn{4}{|c|}{ Highest attained qualification } \\
\hline Matriculation certificate & 34 & 121 & 27.6 \\
\hline Diploma & 31 & 121 & 25.2 \\
\hline Degree & 29 & 121 & 23.6 \\
\hline Postgraduate degree & 27 & 121 & 22.0 \\
\hline \multicolumn{4}{|l|}{ Post held } \\
\hline Administrative & 33 & 123 & 26.8 \\
\hline Other support staff & 30 & 123 & 73.2 \\
\hline
\end{tabular}

$N$, number of participants.

well-being. It consists of statements like 'my life serves a higher purpose', and 'what I do matters to society'. The WBQ has been validated using various samples from different countries (Pouwer et al., 2000). Previous studies reported Cronbach alpha coefficients of between 0.92 and 0.95 (Pouwer et al., 1998).

The Utrecht Work Engagement Scale: The UWES (Schaufeli et al., 2002) is the most commonly used measure of work engagement. Therefore, the researchers used it as a measure of work engagement in this study.

The UWES measures three underlying dimensions of work engagement: vigour, dedication and absorption. It consists of a 17-item, self-reported questionnaire (UWES-17). It distinguishes three dimensions of engagement. These are 'vigour' (six items like 'I am bursting with energy in my work'), 'dedication' (five items like 'I find my work full of meaning and purpose') and 'absorption' (six items like 'when I am working, I forget everything else around $m e^{\prime}$ ) (Schaufeli et al., 2002).

The UWES is scored on a 7-point frequency scale ranging from 0 (never) to 6 (every day). In most cases, the 3-factor structure has been validated for the South African context (Rothmann \& Jordaan, 2006). Internal consistency and reliability for the three subscales fell between 0.68 and 0.91 (Coetzee \& Rothmann, 2005).

The Organisational Commitment Questionnaire: The researchers used the OCQ (Allen \& Meyer, 1990) to measure the affective, continuance and normative organisational 
commitment of the participants. Therefore, three subscales measure the different types of organisational commitment in the OCQ.

The researchers measured responses using a 7-point scale (1 for 'strongly disagree' to 7 for 'strongly agree'). The three subscales of the OCQ are reliable. The Cronbach alpha coefficients for the scales were 0.87 for the affective organisational commitment subscale, 0.75 for the continuance commitment subscale and 0.79 for the normative commitment scale (Allen \& Meyer, 1990). The reliability for the OCQ, as a whole, is reliable. In South African studies, Kwela (2001) found an alpha coefficient of 0.87. Dwyer (2001) found a Cronbach alpha coefficient of 0.79 .

Typical statements include 'I would be very happy to spend the rest of my career with this organisation' and 'I really feel as if this organisation's problems are my own' (Allen \& Meyer, 1990). Cohen (2007) has argued that there is an overlap between the three dimensions.

\section{Statistical analysis}

The researchers conducted the analysis using the SPSS program, version 15 (SPSS Inc., 2003).

They used descriptive statistics to analyse the data. Descriptive statistics consist of means, medians, standard deviations, skewness and kurtosis (Hinton, 1995).

The researchers conducted exploratory factor analysis on the UWES and the OCQ in order to establish how many factors in these scales suited this study's data best.

They conducted exploratory factor analyses to investigate the construct validity of the two-step procedure (Tabachnick \& Fidell, 2001).

Firstly, they conducted a simple principal component analysis on the constructs. They studied the Eigenvalues and scree plots to determine the number of factors.

Secondly, the researchers performed a principal axis factor analysis, with a direct oblimin rotation, to see whether there was a relationship between the factors. They used a principal component analysis, with a varimax rotation, to see whether there was a relationship between the factors that they obtained (Tabachnick \& Fidell, 2001). They performed exploratory factor analysis because it is a powerful statistical tool. Researchers can use it to confirm the underlying factors that fit a particular set of data best in terms of a particular measurement scale (Tabachnick \& Fidell, 2001).
The researchers then used Cronbach alpha coefficients $(\alpha)$ to assess the internal consistency of the measuring instruments (Gregory, 2007). Nunnally and Bernstein (1994) suggest that a Cronbach alpha coefficient of at least 0.70 is an acceptable level of internal consistency.

The researchers used Pearson product-momentum correlation coefficients to identify the relationship between the variables in the study. The level of statistical significance they accepted was $p \leq 0.05$.

Finally, they conducted a linear regression analysis to determine whether happiness (that the SWLS and WBQ measures) and work engagement had predictive value for organisational commitment.

\section{Results}

Table 2 reports the descriptive statistics for all the measures the researchers used in the study. The scores of the SWLS, WBQ, UWES and OCQ have a normal distribution. The researchers used the Cronbach alpha coefficients as an estimate of reliability for all of the measuring instruments. They regarded them all as acceptable compared to the guideline of $\alpha \geq 0.70$ (Nunnally \& Bernstein, 1994). Cronbach's alpha coefficients for the SWLS, WBQ, UWES and OCQ were $0.85,0.78,0.96$ and 0.80 respectively.

The researchers conducted exploratory factor analyses on the UWES and OCQ. For the UWES, the researchers confirmed a 3-factor model for the questionnaire, thus confirming the 3-factor model of Rothmann and Jordaan (2006).

The results of the exploratory factor analysis of the OCQ showed that a 1-factor model suits the data best. The factor analysis showed that the cognitive and normative items of the scale loaded heavily on the affective items of the scale and confirmed Cohen's (2007) discussion of overlapping constructs in the OCQ.

Therefore, for the purpose of this study, the researchers used a 1-factor model that comprised the affective organisational commitment items in the scale.

The researchers used Pearson-momentum correlation coefficients to specify the relationship between the variables in the study. These were happiness (as the SWLS and WBQ measure), affective organisational commitment (as the OCQ measures) and work engagement (as the UWES measures). Table 3 gives the coefficients.

TABLE 2: Descriptive statistics.

\begin{tabular}{|c|c|c|c|c|c|c|c|c|}
\hline Variable & $N$ & Minimum & Maximum & Mean & SD & Skewness & Kurtosis & $\alpha$ \\
\hline Satisfaction with life & 123 & 3 & 28 & 17.47 & 6.331 & -0.346 & -0.894 & 0.85 \\
\hline Well-being & 123 & 40 & 87 & 65.27 & 8.968 & 0.010 & -0.089 & 0.78 \\
\hline Work engagement & 123 & 10 & 101 & 70.47 & 22.758 & -0.818 & -0.093 & 0.96 \\
\hline Affective organisational commitment & 123 & 6 & 30 & 18.85 & 4.672 & -0.178 & 0.190 & 0.80 \\
\hline
\end{tabular}

$N$, number of respondents; $\alpha$, Cronbach alpha coefficients; SD, standard deviation. 
Affective organisational commitment had a statistically and practically significant relationship with work engagement $(p \leq 0.01)$ (large effect) and well-being $(p \leq 0.01)$ (medium effect). In addition, affective organisational commitment had a statistically significant relationship with satisfaction with life $(p \leq 0.05)$. Work engagement had a statistically significant relationship with well-being $(p \leq 0.01)$ and satisfaction with life $(p \leq 0.05)$. Lastly, well-being had a statistically and practically significant relationship with satisfaction with life $(p \leq 0.01)$ (medium effect).

Finally, the researchers conducted regression analyses to determine the percentage variance in the dependent variable (affective organisational commitment). The independent variables (work engagement, well-being and satisfaction with life) explained it.

Therefore, the researchers performed a regression analysis to determine whether happiness (that SWLS and WBQ measure) and work engagement (that UWES measures) can predict affective organisational commitment.

Table 4 shows that subjective well-being and work engagement can predict affective organisational commitment $\left(F=26.191, p \leq 0.01\right.$ and $\left.R^{2}=0.398\right)$. Work engagement, of the three independent variables, had the most statistically significant predictive value for affective organisational commitment $(\beta=0.549$ and $p \leq 0.01)$ when the researchers controlled for the variance that all other variables in the model explain.

Table 4 also shows that well-being has the second highest statistically predictive value for affective organisational commitment $(\beta=0.167$ and $p \leq 0.05)$ when the researchers controlled for the variance that all other variables in the model explained..

However, the researchers did not find a statistically significant predictive relationship between satisfaction with life and affective organisational commitment.

\section{Discussion}

The objective of this study was twofold.

Firstly, it attempted to assess the relationship between the happiness, work engagement and organisational commitment of the support staff at a tertiary education institution in KwaZulu-Natal using a cross sectional design.

Secondly, it attempted to determine whether happiness and work engagement could predict the organisational commitment of the support staff at a tertiary education institution.

The researchers presented the psychometric properties of the Satisfaction with Life Scale (SWLS), the Well-being Questionnaire (WBQ), the Utrecht Work Engagement Scale (UWES) and the Organisational Commitment Questionnaire (OCQ).
TABLE 3: Pearson-momentum correlation coefficients.

\begin{tabular}{|c|c|c|c|c|}
\hline Item & 1 & 2 & 3 & 4 \\
\hline Affective organisational commitment & - & - & - & - \\
\hline Work engagement & $0.604 * * *$ & - & - & - \\
\hline Well-being & $0.331 \dagger * *$ & $0.268 * *$ & - & - \\
\hline Satisfaction with life & $0.224 *$ & $0.216 *$ & $0.347 \div * *$ & - \\
\hline
\end{tabular}
TABLE 4: Regression analysis with 'affective organisational commitment' as
the dependent variable and 'work engagement', 'satisfaction with life' and 'well-being' as the independent variables.

\begin{tabular}{llllll}
\hline Variable & $\boldsymbol{F}$ & $\boldsymbol{\beta}$ & $\mathrm{SE}$ & $\boldsymbol{R}^{2}$ & $\boldsymbol{p}$ \\
\hline- & 26.191 & - & - & 0.398 & $0.000^{* *}$ \\
Constant & - & - & 12.450 & - & 0.064 \\
Work engagement & - & 0.549 & 0.015 & - & $0.000^{* *}$ \\
Satisfaction with life & - & 0.047 & 0.056 & - & 0.538 \\
Well-being & - & 0.167 & 0.040 & - & $0.033^{*}$ \\
\hline
\end{tabular}

$F, F$-test or $F$-statistic; $\mathrm{SE}$, standard error, $R^{2}$, the proportion of variance in one variable accounted for by the other variable; $p$, probability value.

$*$, statistical significance at $p \leq 0.05 ; * *$, statistical significance at $p \leq 0.01$

The findings showed high internal consistency for all of the instruments the researchers used in this study. The researchers used Cronbach alpha coefficients $(\alpha)$ as estimates of the reliability of all of the instruments they used in this study and found them acceptable compared to the guideline of $\alpha \geq 0.70$ (Nunnally \& Bernstein, 1994).

The Cronbach alpha for the SWLS was 0.85. This is slightly higher than Roothman et al. (2003) found. Here the Cronbach alpha was 0.84 .

There was a high level of internal consistency for the SWLS. Cronbach's alpha for the WBQ was 0.78. This is slightly lower than Pouwer et al. (1998) found. However, it is still acceptable according to the guidelines of Nunnally and Bernstein (1994).

Cronbach's alpha for the three subscales of the UWES was 0.96. This is slightly higher than Coetzee and Rothmann (2003) found, where the Cronbach alpha ranged from 0.78 to 0.89 . Therefore, the findings show a high level of internal consistency for the UWES.

Finally, the findings show that Cronbach's alpha for all three subscales of the OCQ was 0.80 , which is slightly lower than Rugg (2002) found. Here the alpha coefficient was 0.87. However, it was slightly higher than Dwyer (2001) found, where the alpha coefficient was 0.79 . Therefore, the findings show a high level of internal consistency for the OCQ.

The researchers conducted exploratory factor analyses on the UWES and the OCQ. The analysis on the UWES showed that a 3-factor model suits the data in this study best. This confirms the discussion of Schaufeli et al. (2002) that the three factors of vigour, dedication and absorption measure engagement. The exploratory factor analysis on the OCQ showed that a 1-factor model suits the data best.

Although Allen and Meyer (1990) propose that one can measure organisational commitment using the 3-factor 
model, other studies (Cohen, 2007; Solinger, Van Olffen \& Roe, 2008), question this model. The findings of the present study confirm Cohen's discussion (2007) about overlapping constructs in the OCQ. Exploratory factor analysis found that the affective commitment component of the OCQ fits the data of this particular study best. This was also consistent with the findings of Somers (1993).

The researchers used Pearson-momentum correlation coefficients to identify the relationship between the variables in the study. They suggested that there is a relationship between happiness (as the WBQ and the SWLS measure), work engagement and organisational commitment. Whilst the findings generally support this hypothesis, other interesting results emerged. Some demographic variables correlated with satisfaction with life (SWLS), well-being (WBQ), work engagement (UWES) and affective organisational commitment (OCQ).

The findings confirmed the first hypothesis of the study that there is a relationship between happiness, work engagement and affective organisational commitment. The findings show that affective organisational commitment has a positive relationship with satisfaction with life, well-being and work engagement. Previous studies, like that of Rothmann and Jordaan (2006), confirm the finding that there is a positive relationship between work engagement and organisational commitment.

A study that Jackson et al. (2006) conducted also found that work engagement is an antecedent of organisational commitment because people who engage deeply with their work are more committed to their organisations. The researchers could find no relevant research in the literature about the relationship between happiness and affective organisational commitment. However, the underlying tenets of the Self Determination Theory (SDT), as mentioned at the beginning of this article, could explain the findings of this study.

The SDT posits that the 'key to autonomous regulation is satisfaction of basic needs' (Meyer \& Gagne, 2008, p. 61). Once people satisfy these basic needs they can experience psychological well-being. This, in turn, links to optimal levels of functioning in organisations and could link to factors like engagement and commitment (Van den Broeck, Vansteenkiste \& De Witte, 2008).

The findings that showed that work engagement has a positive relationship with well-being also confirm the first hypothesis of this study. This means that high levels of work engagement correlate with high levels of well-being. SDT research has consistently shown that people who engage also experience greater levels of well-being (Ryan \& Deci, 2000; Meyer \& Gagné, 2008).

Finally, with regard to the first hypothesis, the findings showed a positive relationship between well-being and satisfaction with life. The SWLS is a measure of well-being
(Diener et al., 1985), as is the WBQ. Both support this finding. Therefore, one can expect a positive relationship between these two variables.

After the researchers completed the literature review and used the SDT (Deci \& Ryan, 1985) as the underlying theoretical framework for this study, they suggested the hypothesis that happiness (as SWLS and WBQ measure) and work engagement can predict organisational commitment.

The researchers showed that this hypothesis was viable because previous studies suggested that factors, like work engagement (Money et al., 2008), lead to happiness in the workplace. The researchers found a positive relationship between work engagement and organisational commitment and that work engagement is an antecedent of organisational commitment (Chalofsky \& Krishna, 2009; Rothmann \& Jordaan, 2006). This led to the second hypothesis of the present study. This was that happiness and work engagement could predict organisational commitment.

The findings partially supported the second and final hypothesis of this study. The findings of the multiple regression analysis showed that work engagement and well-being had statistically significant predictive value for affective organisational commitment.

The researchers found that work engagement was the most predictive of affective organisational commitment when they kept all the other variables constant. Well-being was the second most predictive when they kept all the other variables constant. They found no predictive value for satisfaction with life.

However, one independent variable in the model (satisfaction with life, which the SWLS measures) did not show statistical significance for predicting affective organisational commitment. Barkhuizen and Rothmann (2006) support the findings from the current study: that work engagement is highly predictive of organisational commitment.

In addition, previous research has found that organisational commitment is an aspect of work engagement. This supports the findings of the present study that work engagement has high predictive value for affective organisational commitment (Chalofsky \& Krishna, 2009; Rothmann \& Jordaan, 2006).

However, happiness, which SWLS and WBQ measure, did not show strong predictive value for work engagement. However, well-being did show predictive value for organisational commitment. This is an important and valuable contribution because there has been little research on this relationship.

This finding extends the existing body of knowledge on positive psychology in the context of the workplace because well-being plays a part in predicting the positive organisational outcome of affective organisational commitment. 
The researchers could find very little research that directly investigates happiness as a predictor of work engagement. Therefore, they propose that the findings from this particular study offer insights into a possible relationship between the two constructs. This is consistent with the literature that suggests that happiness has a part to play in harnessing positive organisational outcomes (Money et al., 2008).

This relationship is being researched. Therefore, the researchers propose that more research of this nature is conducted on the SDT to show to what extent happiness predicts organisational commitment.

\section{Limitations of the study}

This study used a cross-sectional research design as opposed to a longitudinal research design. Therefore, the results of this study cannot determine causality between the variables.

Another limitation of this study is that a nonprobability convenience sample may lack generalisability to all support staff in the university or to other universities in South Africa.

In addition, the data came from a self-reported questionnaire. This could affect the reliability and validity of the data because participants may have answered the questions to reflect more socially acceptable responses rather than ones that reflect their real opinions.

\section{Recommendations}

Much research in this area uses a cross-functional type of research design. However, we need more longitudinal studies with large samples so that the findings will predict causal relations between the variables more accurately. This will lead to findings that are more generalisable and accurate.

In a quantitative paradigm, many studies need to validate research to ensure that the findings are generalisable and applicable in a variety of work contexts.

The review of the literature has shown that there has been much research in the area of positive psychology and particularly on the concepts of happiness, work engagement and organisational commitment. However, the link between these three concepts requires attention from researchers. Only when this happens will there be a better understanding of the relationship between them.

\section{Contribution}

People are spending most of their lives in their working environments. Therefore, this study is relevant because it tackles the issue of happiness in the workplace and its relation to other organisational constructs like work engagement and organisational commitment.

The existing research has reported on the predictive value of work engagement for organisational commitment. Therefore, the present study has contributed to the existing positive psychology literature through an increased insight into how work engagement and happiness can predict organisational commitment.

These research findings will benefit all parties in the workplace. The current research will help organisations to improve organisational outcomes and organisational commitment specifically. It will also help organisations to understand workers, particularly their levels of happiness, and what benefits their happiness can bring.

Organisations can use the finding of this study to develop interventions and strategies for improvement.

\section{Acknowledgements Authors' contributions}

L.F. was the main researcher and wrote the manuscript. J.B. was the supervisor.

\section{Author competing interests}

The authors declare that they have no financial or personal relationship(s) which may have inappropriately influenced them in writing this paper.

\section{References}

Alexandrova, A. (2005). Subjective Well-being and Kahneman's 'Objective Happiness'. Journal of Happiness Studies, 6, 301-324. doi:10.1007/s10902-005-7694-x

Allen, N.J., \& Meyer, J.P. (1991). A Three-Component Conceptualization of Organisational Commitment. Human Resources Management Review, 1, 61-89. doi:10.1016/1053-4822(91)90011-Z

Allen, N.J., \& Meyer, J.P. (1990). The Measurement and Antecedents of Affective, Continuance and Normative Commitment to the Organisation. Journal of Occupational Psychology, 63, 1-18.

Bakker, A.B., \& Demerouti, E. (2008). Towards a model of work engagement. Career Development International, 13, 209-223. doi:10.1108/13620430810870476

Bakker, A.B., Schaufeli, W.B., Leiter, M.P., \& Taris, W.T. (2008). Position Paper: Work Engagement: An Emerging Concept in Occupational Health Psychology. Work \& Stress, 22, 187-200. doi:10.1080/02678370802393649

Barkhuizen, N., \& Rothmann, S. (2006). Work Engagement of academic staff in South African higher education institutions. Management Dynamics, 15, 38-46.

Bradley, C. (1994). The Well-being Questionaire (W-BQ). In C. Bradley (Ed.), Handbook of Psychology and Diabetes: A Guide to Psychological Measurement in Diabetes Research and Practice (pp. 89-109). Chur, Switzerland: Harwood Academic Publishers.

Brooks, P.W. (2006). Trends in Employee Engagement Tenure and Age. Talent Performance LLC. Retrieved August 08, 2010, from http://talentperformance. com/index.html

Cankaya, Z.C. (2009). Autonomy Support, Basic Psychological Need satisfaction and Subjective Well-Being: Self-Determination Theory. Turkish Psychological Counselling and Guidance Journal, 4, 23-31.

Chalofsky, N., \& Krishna, V. (2009). Meaningfulness, Commitment, and Engagement: The Intersection of a deeper Level Intrinsic Motivation. Advances in Developing Human Resources, 11, 189-203. doi:10.1177/1523422309333147

Charles, S.T., Reynolds, C.A., \& Gatz, M. (2001). Age-Related Differences and Change in Positive and Negative Affect over 23 Years. Journal of Personality and Social Psychology, 80, 136-151.

Coetzee, S.E., \& Rothmann, S. (2005). Work Engagement of employees at a higher education institution in South Africa. Southern African Business Review, 9, 23-34.

Cohen, J. (2007). Commitment Before and After: An Evaluation and Reconceptualisation of Organisational Commitment. Human Resource Management Review, 17, 336354. doi:10.1016/j.hrmr.2007.05.001

Cohen, J. (1988). Statistical Power Analysis for Behavioural Sciences. (2nd edn.). Hillsdale, NJ: Lawrence Erlbaum \& Associates.

Deci, E.L., \& Ryan, R.M. (1985). Intrinsic Motivation and Self-Determination in Human Behaviour. New York: Plenum.

Deci, E.L., \& Ryan, R.M. (2000). The 'What' and 'Why' of Goal Pursuits: Human Needs and the Self-Determination of Behavior. Psychological Inquiry, 11, 227-268. doi:10.1207/S15327965PLI1104_01

Diener, E., Emmons, R.A., Larsen, R.J., \& Griffon, S. (1985). The Satisfaction with Life Scale. Journal of Personality Assessment, 49, 71-74. doi:10.1207/ s15327752jpa4901_13, PMid:16367493 
Dwyer, T.C. (2001). Psychological Empowerment Within a Manufacturing Environment Unpublished master's thesis, PU for CHE, Vanderbijlpark, South Africa.

Fisher, C.D. (2010). Happiness at Work. International Journal of Management Reviews, 12, 384-412. doi:10.1111/j.1468-2370.2009.00270.x

French, W.L., \& Bell, C.H. (1991). Organization Development: Behavioural Science Interventions for Organization Improvement. (6th edn.). London, UK: Prentice Hall.

Gagne, M. \& Deci, E.L. (2005). Self-Determination Theory and Work Motivation. Journal of Organizational Behaviour, 26, 331-362. doi:10.1002/job.322

Gavin, J.H., \& Mason, R.O. (2004). The Virtuous Organisation: The Value of Happiness in the Workplace. Organisational Dynamics, 33, 379-392. doi:10.1016/j. orgdyn.2004.09.005

Gilbert, A.C. (2001). Work Absorption: Causes Among Highly Educated Workers and Consequences for their Families. Unpublished master's and doctoral thesis, University of California, Berkeley.

Gregory, R.J. (2007). Psychological Testing: History, Principles, and Applications. (5th edn.). Boston, MA: Pearson.

Hinton, P.R. (1995). Statistics Explained: A Guide for Social Science Students. New York: Routledge.

Holt-Lunstad, J., Birmingham, W., \& Jones, B.Q. (2008). Is There Something Unique About Marriage? A Relative Impact of Marital Status, Relationship Quality, and Network Social Support in Ambulatory Blood Pressure and Mental Health Annual Behavioural Medicine, 35, 239-244. doi:10.1007/s12160-008-9018-y, Annual Behaviourc 18347896

Howell, D.C. (1995). Fundamental Statistics for the Behavioural Sciences. Belmont: Duxbury Press.

Huysamen, G.K. (1994). Methodology for the Social and Behavioural Sciences. Pretoria: Southern Book Publishers.

Iqbal, A. (2010). An Empirical Assessment of Demographic Factors, Organizational Ranks and Organizational Commitment. International Journal of Business Management, 5, 16-27.

Jackson, L.T.B., \& Rothmann, S. (2005). Work-related Well-Being of Educators in a District of North-West Province. Perspectives in Education, 23, 107-122.

Jackson, L.T.B., Rothmann, S., \& Van de Vijver, F.J.R. (2006). A model of work-related well-being for educators in South Africa. Stress and Health, 22, 263-274. doi:10.1002/smi.1098

Kahn, W.A. (1990). Psychological Conditions of Personal Engagement and Disengagement at Work. Academy of Management Journal, 33, 697-724. doi:10.2307/256287

Kahneman, D. (2000). Experienced Utility and Objective Happiness: A Moment Based Approach. In D. Kahneman, \& V. Tversky (Eds.), Choices, Values and Frames (pp. 673-693). New York: Russell Sage Foundation, Cambridge University Press.

Kwela, S.M. (2001). Organisational Commitment and Job Satisfaction of Non Academic Personnel at a Tertiary Institution. Unpublished master's thesis, PU for $\mathrm{CHE}$, Vanderbijlpark, South Africa.

Maddux, J.E. (2008). Positive Psychology and the Illness Ideology: Toward a Positive Clinical Psychology. Applied Psychology: An International Review, 57, 54-70. doi:10.1111/j.1464-0597.2008.00354.x

Meyer, J.P., \& Gagné, M. (2008). Employee Engagement from a Self-Determination theory Perspective. Industrial and Organisational Psychology, 1, 60-62. doi:10.1111/j.1754-9434.2007.00010.x

Meyer, J.P., Stanley, J.S., Herscovitch, L., \& Topolnytsky, L. (2002). Affective, Continuance, and Normative Commitment to the Organization: A Meta-analysis of Antecedents, Correlates, and Conseg
16, 20-52. doi:10.1006/jvbe.2001.1842

Money, K., Hillenbrand, C., \& Da Camara, N. (2008). Putting Positive Psychology to Work in Organisations. Journal of General Management, 34, 21-36.

Mroczek, D.K., \& Kolarz, C.M. (1998). The Effect of Age on Positive and Negative Affect: A Developmental Perspective of Happiness. Journal of Personality and Socia Psychology, 75, 1333-1349. doi:10.1037/0022-3514.75.5.1333, PMid:9866191

Nunnally, J.C., \& Bernstein, I.H. (1994). Psychometric Theory. (3rd edn.). New York: McGraw-Hill.

Peterson, C., Park, N., \& Seligman, M.E.P. (2005). Orientations to Happiness and Life Satisfaction. Journal of Happiness Studies, 6, 25-41. doi:10.1007/s10902-004 1278-z

Pitt-Catsouphes, M., \& Matz-Costa, C. (2008). The Multi-Generational Workforce: Workplace Flexibility and Engagement. Community, Work \& Family, 11, 215-229. doi:10.1080/13668800802021906, PMid:2576907

Porters, L.W., Steers, R.M., Mowday, R.T., \& Boulin, P.V. (1974). Organizational Commitment, Job Satisfaction, and Turnover Among Psychiatric Technicians. Journal of Applied Psychology, 59, 603-609. doi:10.1037/h0037335

Pouwer, F., Snoek, F.J., Van der Ploeg, H.M., Adér, H.J., \& Heine, R.J. (2000). The WellBeing Questionnaire: Evidence for a Three-Factor Structure with 12 Items (WBQ12). Psychological Medicine, 30, 455-462. doi:10.1017/S0033291700001719, PMid:10824665
Pouwer, F., Snoek, F.J., Van der Ploeg, H.M., Heine, R.J., \& Brand, A.N. (1998). A Comparison of the Standard and the Computerized Versions of the Well-Being Questionnaire (WBO) and the Diabetes Treatment Satisfaction Questionnaire (DTSQ). Quality of Life Research, 7, 33-38. doi:10.1023/A:1008832821181

Rhoades, L., Eisenberger, R., \& Armeli, S. (2001). Affective Commitment to the Organisation: The Contribution of Perceived Organisational Support. Journal of Applied Psychology, 86, 825-836. doi:10.1037/0021-9010.86.5.825, PMid:11596800

Robinson, S.M., Kraatz, L.S., \& Rousseau, D.M. (1994). Changing Obligations and the Psychological Contract: A Longitudinal Study. Academy of Management Journal, 37, 137-152. doi:10.2307/256773

Roothman, B., Kirsten, D., \& Wissing, M. (2003). Gender Difference in Psychological Aspects of Wellbeing. South African Journal of Psychology, 33, 212-218.

Rothmann, S., \& Jordaan, G.M.E. (2006). Job demands, Job Resources and work Engagement if Academic Staff in Southern African Higher Education Institutions. South African Journal of Industrial Psychology, 32, 87-96.

Rugg, J.S. (2002). Psychological Empowerment within a University. Unpublished master's thesis, PU for CHE, Vanderbijlpark, South Africa.

Ryan, R.M., \& Deci, E.L. (2001). On Happiness and Human Potentials: A Review of Research on Hedonic and Eudaimonic Well-Being. Annual Review Psychology, 52, 141-166.

Ryan, R.M., \& Deci, E.L. (2000). Self-Determination Theory and The Facilitation of Intrinsic Motivation, Social Development and Well-being. American Psychologist, 55, 68-78. doi:10.1037/0003-066X.55.1.68, PMid:11392867

Ryan, R.M., Huta, V., \& Deci, E.L. (2008). Living Well: A Self Determination Theory Perspective of Eudaimonia. Journal of Happiness Studies, 9, 139-170. doi:10.1146/ annurev.psych.52.1.141, PMid:11148302

Saks, A.M. (2006). Antecedents and Consequences of Employee Engagement. Journa of Managerial Psychology, 21, 600-619. doi:10.1108/02683940610690169

Schaufeli, W.B., \& Bakker, A.B. (2006). The Measurement of Work Engagement with a Short Questionnaire: A Cross-National Study. Educational and Psychological Measurement, 66, 701-716. doi:10.1177/0013164405282471

Schaufeli, W.B., \& Bakker, A.B. (2004). Job Demands, Job Resources, and their relationship with Burnout and Engagement: A Multi-Sample Study. Journal of Organizational Behaviour, 25, 293-315. doi:10.1002/job.248

Schaufeli, W.B., Salanova, M., Gonzalez-Roma, V., \& Bakker, A.B. (2002). The Measurement of Engagement and Burnout: A Two-Sample Confirmatory Factor Analytic Approach. Journal of Happiness Studies, 3, 71-92. doi:10.1023/A:1015630930326

Seligman, M.E.P., \& Csikszentmihalyi, M. (2000). Positive Psychology: An Introduction. American Psychologist, 55, 5-14. doi:10.1037/0003-066X.55.1.5, PMid:11392865

Shaughnessy, J.J., \& Zechmeister, E.B. (1997). Research Methods in Psychology. (4th edn.). NewYork: McGraw-Hill.

Solinger, O.N., Van Olffen, W., \& Roe, R.A. (2008). Beyond the Three-Component Model of Organizational Commitment. Journal of Applied Psychology, 93, 70-83. doi:10.1037/0021-9010.93.1.70, PMid:18211136

Somers, M.J. (1993). A test of the relationship between affective and continuance commitment using non-recursive models. Journal of Occupational and Organisational Psychology, 66, 185-192.

SPSS 12.0 for Windows [Computer software] (2003). Chicago, IL: SPPS Inc.

Susniene, D., \& Jurkauskas, A. (2009). The Concepts of Quality of Life and happiness -Correlation and Differences. Inzinerine Ekonomika-Engineering Economics, 3 , 58-65.

Tabachnick, B.G., \& Fidell, L.S. (2001). Using Multivariate Statistics. (4th edn.). Boston, MA: Allyn \& Bacon.

Towers Perrin. (2005). The Business Case for Workers age 50+: Plannning for Tomorrow's Talent Needs in today's competitive environment. Wahsington, DC: AARP. Retrieved June 21, 2010, from http://assets.aarp.org/rgcenter/econ/ workers_fifty_plus.pdf

Uchida, Y., Norasakkunkit, V., \& Kitayama, S. (2004). Cultural Constructions of Happiness: Theory and Empirical Evidence. Journal of Happiness Studies, 5, 223239. doi:10.1007/s10902-004-8785-9

Van den Broeck, A., Vansteenkiste, M., \& De Witte, H. (2008). Self-determination theory: A theoretical and empirical overview in occupational health psychology. In J. Houdmont, \& S. Leka (Eds.), Occupational health psychology: European perspectives on research, education, and practice (Vol. 3, pp. 63-88). Nottingham, perspectives on research, education,

Viljoen, J.P., \& Rothmann, S. (2009). Occupational Stress, III Health and Organisational Commitment of Employees at a University of Technology. South African Journal of Industrial Psychology, 35, 1-11.

Winefield, A.H., Gillespie, N., Stough, C., Dua, J., \& Hapuararchchi, J. (2002). Occupational Stress in Australian Universities: A National Survey. Melbourne: National Tertiary Education Union. 